\title{
EDITING THE TIMES
}

\section{ANNE ALLISON \\ CHARLES PIOT \\ Duke University}

Every editorship is faced with constraints and possibilities, ones arising from the world and times in which we live and others embedded in the practice and politics of the publishing medium we are tasked with stewarding. As editors of Cultural Anthropology between 2010 and 2014, we oversaw a historic moment of movement and flux, but also of uncertainty and constriction. It was a time of global precarity and financialization, of state pullback and NGO-ization, of migration and stuckedness. It was also a time of rapid change and challenge in the academy when publishing was becoming digitized, the classroom was going online, and the humanities and interpretive social sciences were increasingly under attack and at risk. Cultural Anthropology, from its inception, has been a journal that has attempted to capture and resonate with the times. As editors, we sought to remain true to the journal's experimental and dynamic history - its commitment to innovative scholarship and brilliant writing, to pushing the anthropological envelope in form as well as content, and to publishing pieces that conjured that magical mix of theory and ethnography — while also ensuring that the journal's pages gave voice to the distinctiveness of the times in which we were living.

To begin, we embraced the important work begun by Kim and Mike Fortun of enhancing the journal's web presence (see Fortun and Fortun 2015) by migrating significant amounts of journal content online-supplemental pages (of 
author interviews, photos and videos, and suggested reading), curated collections of already-published articles, teaching tools, and much more. Over 1,400 pages of content are now available online, thanks to the tireless labors of our two managing editors, Ali Kenner and Tim Elfenbein, and of dozens of graduate student interns from departments around the country. One of the more gratifying aspects of editing the journal was discovering the ways in which Cultural Anthropology has become a collective project of present and past board members of the Society for Cultural Anthropology (SCA), former editors, authors, reviewers, and graduate students.

We also added new features to the website. One of these in particular, Hot Spots, became an instant hit and a source of unending surprise. These sets of short essays addressing politically volatile events - the Greek debt crisis (Papailias 2011), the Ebola epidemic (Moran and Hoffman 2014), the Occupy movement (Juris and Razsa 2012), self-immolations in Tibet (McGranahan and Litzinger 2012), the Soviet land grab in Ukraine (Ries 2014), Japan's post-tsunami nuclear meltdown (Slater 2011), the protests at Tahrir Square (Elyachar and Winegar 2012) and Gezi Park (Ylldırım and Navaro-Yashin 2013), among others-were an attempt to get anthropological voices out into the public sphere in a quick, timely fashion. Since we insisted on compressed (one-thousand-word) pieces and no more than fifteen contributors, an entire series could be assembled in a few weeks and published within days of completion. Remarkably, given contemporary speed-up and work fatigue, few of those we approached to curate or contribute to these series turned us down. This would seem to indicate a strong desire on the part of anthropologists not only to have a more immediate say in ongoing events, but also to embrace the short essay format. Moreover, these Hot Spots features had vastly larger readerships than regular journal articles, as well as audiences far beyond the academy.

Perhaps our signature intervention as editors was taking the journal open access-leaving Wiley-Blackwell, the American Anthropological Association's (AAA) commercial publisher, to become our own publisher, while making the journal freely available to anyone anywhere who has access to our website. Among other things, going open access meant an enormous amount of additional labor upfront. While continuing the job of curating the journal-reading hundreds of manuscripts a year, selecting and publishing around thirty — we had to get up to speed on the Open Access movement, convene working groups to discuss its pluses and minuses, write memos, politick, and then (when Wiley and the AAA approved the move) oversee the building of the infrastructure necessary to become 
a publishing organization (see Elfenbein 2014). We also spent much time on the key issue of funding - how to finance the journal when it could no longer rely on a revenue stream from subscriptions - an issue that we continue to work on. Again, we had an army of helpers and supporters - Kim and Mike Fortun, Chris Kelty, Jason Jackson, the SCA board, the graduate student interns, and the brilliant, brick-by-brick infrastructural labor of our managing editor Tim Elfenbein.

Open access took us deep into the politics of publishing, and we found it surprising that there was so little general awareness of it among the AAA's membership - a constituency that is otherwise politicized and activist. Today's world of academic publishing is scandalous in at least two senses. First, academics produce articles that are the product of the intellectual commons of which we are all a part — of colleague and student input, of reading group and seminar vetting, of constructive criticism by journal reviewers and editors. It is these (unremunerated) labors that make journal articles into objects of value. We then freely hand them over to a commercial press, which adds a small amount of valuetypesetting and distribution (all form, no content) — before selling them back to the same universities who produced their value to begin with, at exorbitant rates, while making obscene profits (often over 40 percent) and bankrupting university libraries in the process. Why are we hurting universities and helping publishers like this? Second, how can we justify a practice in which our publications are accessible only to those who can afford to get behind the commercial press's firewall, either because they are faculty or students at a university that can pay or because they can purchase the article themselves? This means, of course, that most of those among whom anthropologists live and work, and about whom we write, will be unable to access our writings. Neither of these concessions makes any sense in a profession that prides itself on ethical conduct.

Another signal feature of our editorship was our attempt to ensure that the journal captured the changing present of the times in which we live-which we regularized through an annual feature called Futures of Neoliberalism. This stimulated, but also responded to, what we found to be a marked tendency in the submissions we received throughout the four years to treat subjects struggling and innovating with uncertainty, insecurity, risk, and stuckedness. Exemplary cases came in various forms during our editorship — of pyramid schemes in Albania (Musaraj 2011), garbage pickers in Brazil (Millar 2014), soldiers laboring at war in Sierra Leone (Hoffman 2011), and suicidal youth in Kerala (Chua 2011). Needless to say, there is nothing necessarily new about unpredictability and risk. But the shape and effect(s) of insecuritization today, entangled as it is with globali- 
zation, affected by privatization and state deregulation, and conditioned by a temporality that is sped up for some while remaining interminably stagnant for others (those waiting - forever, it seems - for citizenship, or just to find shelter and food), also bear very specific qualities that harbor particular constraints and possibilities for anthropologists working in these times.

The demand on the anthropologist is that we encounter and study who/ what/where we work in both a timely and untimely fashion-this latter, in the sense suggested by Paul Rabinow (2009), is what distinguishes our work from that of journalists. This double challenge - remaining timely and untimely - must be taken up first as ethnographic method, as we found in the innovative field designs of submissions that ranged from diagnosing a particular mode of being among bored and homeless men in Romania (O’Neill 2014) or the everyday politics of members of the Occupy movement (Appel 2014) and welfare volunteers in Italy (Muehlebach 2011) to documenting the survival strategies of a kidnapping victim in Iraq (Al-Mohammad 2012) or a Nicaraguan woman who couldn't get out of bed in the morning (Nouvet 2014). Other submissions tracked the temporalities of anthropological fieldwork, whether in Venezuelan mourning rituals (Briggs 2014) or the pacing of filmmaking in South India (Pandian 2012). All of these submissions were marked by a method of untimely timeliness that remains attuned to stories told by the ethnographer as well as those among whom she works, and that goes beyond the surfeit of information-and, now, of data and sound bites - that Walter Benjamin (1969) decried as standing for "news" in the modern era. These articles and others like them exemplify a method that speaks to what Akhil Gupta and James Ferguson (1997) call location rather than (bounded, grounded) locale, to unknown futures, dislocated pasts, and presents characterized by the implosion of the everyday into the materiality of well-being/ getting by/speculation and risk.

But how to theorize life lived increasingly under conditions of insecurity and disjuncture? How to be not only ethnographers but also theorists of the times and worlds in which we live? The two projects are connected, of course, and what we saw during our tenure as editors was theorizing driven by ethnography that - in grasping, excavating, and sensing the complexities and murkiness of a time of uncertainty - offered what might be considered an immanent theory of temporality, materiality, hope and despair, value, and the social, all inflected by capitalist fetishism and the everyday freneticism of living in precarious times. Theorizing, then, is also a possibility yielded by the times - and the challenge is how to better realize and promote it. To wit, how to use our skills as ethnog- 
raphers to understand how people are living the times and to build this into a theoretics and politics of the moment?

We immensely enjoyed our editorship of Cultural Anthropology. But we were also happy to pass this role on to the next editorial team: Dominic Boyer, Cymene Howe, and James Faubion. Under their stewardship, the journal is sure to flourish in new and exciting ways.

\section{REFERENCES}

Al-Mohammad, Hayder

2012 "A Kidnapping in Basra: The Struggles and Precariousness of Life in Post-Invasion Iraq.” Cultural Anthropology 27, no. 4: 597-614. http://dx.doi.org/10.1111/ Appel, Hannah j.1548-1360.2012.01163.x

2014 “Occupy Wall Street and the Economic Imagination.” Cultural Anthropology 29, no. 4: 602-25. http://dx.doi.org/10.14506/ca29.4.02

Benjamin, Walter

1969 "The Storyteller: Reflections on the Works of Nikolai Leskov." In Illuminations: Essays and Reflections, translated by Harry Zohn and edited by Hannah Arendt, 83-110. New York: Schocken Books. Originally published in 1936.

Briggs, Charles

2014 “Dear Dr. Freud.” Cultural Anthropology 29, no. 2: 312 43. http://dx.doi.org/ $10.14506 / \mathrm{ca} 29.2 .08$

Chua, Jocelyn Lim

2011 "Making Time for the Children: Self-Temporalization and the Cultivation of the Antisuicidal Subject in South India." Cultural Anthropology 26, no. 1: 112-37. http://dx.doi.org/10.1111/j.1548-1360.2010.01082.x

Elfenbein, Timothy W.

2014 "Cultural Anthropology and the Infrastructure of Publishing." Cultural Anthropology 29, no. 2: 288-303. http://dx.doi.org/10.14506/ca29.2.06

Elyachar, Julia, and Jessica Winegar, eds.

2012 "Revolution and Counter-Revolution in Egypt A Year after January 25th." Hot Spots series, Cultural Anthropology website, February 2. http://www.culanth. org / fieldsights / 208-revolution-and-counter-revolution-in-egypt-a-year-afterjanuary-25th

Fortun, Kim, and Mike Fortun

2015 “An Infrastructural Moment in the Human Sciences." Cultural Anthropology 30, no. 3: 359-67. http://dx.doi.org/10.14506/ca30.3.01

Gupta, Akhil, and James Ferguson, eds.

1997 Anthropological Locations: Boundaries and Grounds of a Field Science. Berkeley: University of California Press.

Hoffman, Daniel

2011 "Violence, Just in Time: War and Work in Contemporary West Africa." Cultural Anthropology 26, no. 1: 34-57. http://dx.doi.org/10.1111/j.1548-1360. 2010.01079.x

Juris, Jeffrey, and Maple Razsa, eds.

2012 “Occupy, Anthropology, and the 2011 Global Uprisings." Hot Spots series, Cultural Anthropology website, July 27. http://www.culanth.org/fieldsights/63occupy-anthropology-and-the-2011-global-uprisings 
McGranahan, Carole, and Ralph Litzinger, eds.

2012 "Self-Immolation as Protest in Tibet." Hot Spots series, Cultural Anthropology website, April 9. http://www.culanth.org/fieldsights/93-self-immolation-as-

Millar, Kathleen protest-in-tibet

2014 "The Precarious Present: Wageless Labor and Disrupted Life in Rio de Janeiro, Brazil.” Cultural Anthropology 29, no. 1: 32-53. http://dx.doi.org/10.14506/ ca29.1.04

Moran, Mary, and Daniel Hoffman, eds.

2014 "Ebola in Perspective." Hot Spots series, Cultural Anthropology website, October

7. http://www.culanth.org/fieldsights/585-ebola-in-perspective

Muehlebach, Andrea

2011 “On Affective Labor in Post-Fordist Italy." Cultural Anthropology 26, no. 1: 59Musaraj, Smoki 82. http://dx.doi.org/10.1111/j.1548-1360.2010.01080.x

2011 "Tales From Albarado: The Materiality of Pyramid Schemes in Postsocialist Albania." Cultural Anthropology 26, no. 1: 84-110. http://dx.doi.org/10.1111/

Nouvet, Elysée j.1548-1360.2010.01081.x

2014 "Some Carry On, Some Stay in Bed: (In)convenient Affects and Agency in Neoliberal Nicaragua.” Cultural Anthropology 29, no. 1: 80-102. http:// dx.doi.org/10.14506/ca29.1.06

O’Neill, Bruce

2014 "Cast Aside: Boredom, Downward Mobility, and Homelessness in PostCommunist Bucharest." Cultural Anthropology 29, no. 1: 8-31. http://dx.doi. org/10.14506/ca29.1.03

Pandian, Anand

2012 "The Time of Anthropology: Notes from a Field of Contemporary Experience." Cultural Anthropology 27, no. 4: 547-71. http://dx.doi.org/10.1111/j.15481360.2012.01161.x

Papailias, Penelope, ed.

2011 "Beyond the 'Greek Crisis': Histories, Rhetorics, Politics." Hot Spots series, Cultural Anthropology website, October 10. http://www.culanth.org/fieldsights/ 243-beyond-the-greek-crisis-histories

Rabinow, Paul

2009 “Foucault's Untimely Struggle: Toward a Form of Spirituality." Theory, Culture \& Society 26, no. 6: 25-44. http://dx.doi.org/10.1177/0263276409347699

Ries, Nancy, ed.

2014 “Ukraine and Russia: The Agency of War." Hot Spots series, Cultural Anthropology website, October 28. http://www.culanth.org/fieldsights/610-ukraine-andrussia-the-agency-ofwar

Slater, David H., ed.

2011 "3.11 Politics in Disaster Japan: Fear and Anger, Possibility and Hope." Hot Spots series, Cultural Anthropology website, July 26. http://www.culanth.org/ fieldsights /416-3-11-politics-in-disaster-japan-fear-and-anger-possibility-andhope

Yıldırım, Umut, and Yael Navaro-Yashin, eds.

2013 "An Impromptu Uprising: Ethnographic Reflections on the Gezi Park Protests in Turkey." Hot Spots series, Cultural Anthropology website, October 31. http:// www.culanth.org/fieldsights/391-an-impromptu-uprising-ethnographicreflections-on-the-gezi-park-protests-in-turkey 